\title{
Aneurysmal bone cyst of the maxillary sinus secondary to fibrous dysplasia: Report of a rare case and review of the literature
}

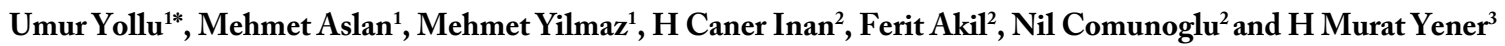 \\ ${ }^{1}$ Gumushane Public Hospital, Otorhinolaryngology Clinic, Turkey \\ ${ }^{2}$ Istanbul University Cerrahpasa Medical School Otorhinolaryngology Department \\ ${ }^{3}$ Istanbul University Cerrahpasa Medical School Pathology Department
}

\begin{abstract}
$\mathrm{ABC}$ developing within FD in head and neck region is quite rare. Clinical presentation of FD and ABC depends on the location and scope of content. The majority of reported cases were seen in male children and adolescents. Complete excision of these lesions is the recommended treatment.This report is about a 27 year-old male patient who presented with a mass in hard palate treated with total excision.
\end{abstract}

\section{Introduction}

Fibrous Dysplasia (FD) is a benign skeletal disease in which medullary bone is replaced with fibrocellular tissue. It results from abnormal fibroblast development [1]. Aneurysmal Bone Cysts (ABC) are relatively rare, benign vascular lesions and also may exist secondary to the pathological bone lesions [2].

$\mathrm{FD}$ in combination $\mathrm{ABC}$ that appears as a symptomatic or asymptomatic mass is quite rare. Clinical presentation of FD and $\mathrm{ABC}$ depends on the location and scope of content. The majority of reported cases are seen in male children and adolescents. Complete excision of these lesions is recommended.

\section{Case report}

27 year old male patient admitted to our clinic with complaints of swelling in hard palate and toothache. Medical history was unremarkable, and general health condition was well. On physical examination, a $4 \times 5 \mathrm{~cm}$ soft mass was seen on the middle part of the hard palate. The overlying mucosa was intact and bony consistency of the hard palate could not be palpated. Nasal endoscopy was unremarkable.

Paranasal sinus CT scan revealedthat the lesion was originating from the inferior wall of the maxillary sinus and was surrounding the left posterior molar teeth. The central part of the lesion had soft tissue dansity, periferal areas had ground glass opacity and the nature of the lesion was expansile (Figure 1). Age and radiological findings of the patient were compatible with the fibrous dysplasia.

Caldwell-Luc antrostomy was performed and the lesion that filled the maxillary sinus and expanding to hard palate was totally excised with blunt dissection. Inferior antrostomy was done and stabilisated with a rubber drain. Histopathological examination was reported as aneurysmal bone cystsecondary to fibrous dysplasia with woven bone formation and short spindle cells within the stroma (Figures 2 and 3).

\section{Literature review and discussion}

Fibrous dysplasia which was first described by Lichtenstein [3] constitutes $2,5 \%$ of all bone tumors and $\% 7$ of benign bone tumors [4]. It is often seen in young male patients. FD can present as monostotic $(\% 70)$ or polystotic (\%30) disease and may be a component of McCuneAlbright syndrome [5]. At the craniofacial area; maxilla, mandible, frontal and temporal bones are the most frequent sites of ivolvement. CT images usually reveal extensive diploic spaces, enlargement and ground glass opacity of the affected bones and MRI shows typically low signal intensity on T1 and T2-weighted images [6].

$\mathrm{ABC}$ can be seen about $1.4 \%$ of all bone tumors but only $3-6 \%$ of them present in the cranium [7]. ABC mostly affect patients under under 20 years without gender difference [8]. Fluid-filled cavities are common and can be detected on CT or MR images [9]. On histopathologic examination; ABC present with blood-filled cavernous spaces which are usually seperated by fibrous tissue.

This report presents a case who was diagnosed as concominant FD and $\mathrm{ABC}$. The occurance of $\mathrm{ABC}$ in combination with FD in the head and neck region is extremely rare. Up to date only several cases has been reported and most of these cases the disease is located on the skull base with only 3 cases of maxilla involvement. The cases of concomitant FD and $\mathrm{ABC}$ on the sinonasal region are summarized in Table 1 [10-14].

The presentation of these lesions depends on the sites of involvement, growth rate and anatomic structures of the involved region. Craniofacial lesions usually present with symptoms resulting

Correspondence to: Umur Yollu, Department of Otorhinolaryngology, Cerrahpasa Medical School, Istanbul University, Fatih, Istanbul, Turkey, Tel: +90 21241430 00, E-mail: umuryollu@hotmail.com

Received: October 01, 2017; Accepted: October 23, 2017; Published: October 27,2017 
Table 1. Fibrous dysplasia with aneurysmal bone cysts at the sinonasal region

\begin{tabular}{|c|c|c|c|c|c|c|}
\hline Reference & $\begin{array}{l}\text { Age (years) } \\
\text { Gender }\end{array}$ & Symptoms & Localization & Radiological findings & Treatment & Following period \\
\hline Saito et al. 1998 [10] & $11 / \mathrm{M}$ & $\begin{array}{l}\text { Nasal obstruction for } \\
1 \text { year }\end{array}$ & $\begin{array}{l}\text { Nasal cavity and } \\
\text { sphenoid bone }\end{array}$ & $\begin{array}{l}\mathrm{CT} \text { and MRI, irregular } \\
\text { multilobulated tumor }\end{array}$ & Surgical excision & $\begin{array}{l}\text { No recurrence for } 3.5 \\
\text { years follow-up }\end{array}$ \\
\hline $\begin{array}{l}\text { Skaladzien et al. } 2008 \\
\text { [11] }\end{array}$ & $16 / \mathrm{M}$ & $\begin{array}{l}\text { Rhinosinusitis and } \\
\text { epistaxis }\end{array}$ & Right maxillary sinus & Large cystic lesion & Surgical excision & $\begin{array}{l}\text { No recurrence for } 9 \\
\text { months follow up }\end{array}$ \\
\hline Pasquini et al. 2002 [12] & $5 / \mathrm{M}$ & $\begin{array}{l}\text { Chronic rhinosinusitis for } \\
2 \text { years }\end{array}$ & Right maxillary sinus & CT: Cystic lesion & $\begin{array}{l}\text { Transnasal endoscopic } \\
\text { surgery }\end{array}$ & No follow-up \\
\hline Lin et al. 2004 [13] & $18 / \mathrm{M}$ & Mass with headache & Left frontal bone & CT: Cystic spaces & Surgical excision & No follow- up \\
\hline Terkawi et al. 2011 [14] & $7 / \mathrm{F}$ & $\begin{array}{l}\text { Left nasal obstruction } \\
\text { and left eye blindness }\end{array}$ & $\begin{array}{l}\text { Sphenoid and ethmoid } \\
\text { bones }\end{array}$ & CT-MR: Cystic lesion & $\begin{array}{l}\text { Endonasal - cranial } \\
\text { resection }\end{array}$ & $\begin{array}{l}\text { Recurrence was revealed } \\
\text { after } 5 \text { months }\end{array}$ \\
\hline Our case & $27 / \mathrm{M}$ & $\begin{array}{l}\text { Toothache and mass at } \\
\text { hard palate }\end{array}$ & $\begin{array}{l}\text { Left maxillary sinus and } \\
\text { bone }\end{array}$ & $\begin{array}{l}\text { CT: Expansile mass in } \\
\text { the left maxillary sinus }\end{array}$ & Surgical resection & $\begin{array}{l}\text { No recurrence for } 2 \text { years } \\
\text { follow-up }\end{array}$ \\
\hline
\end{tabular}

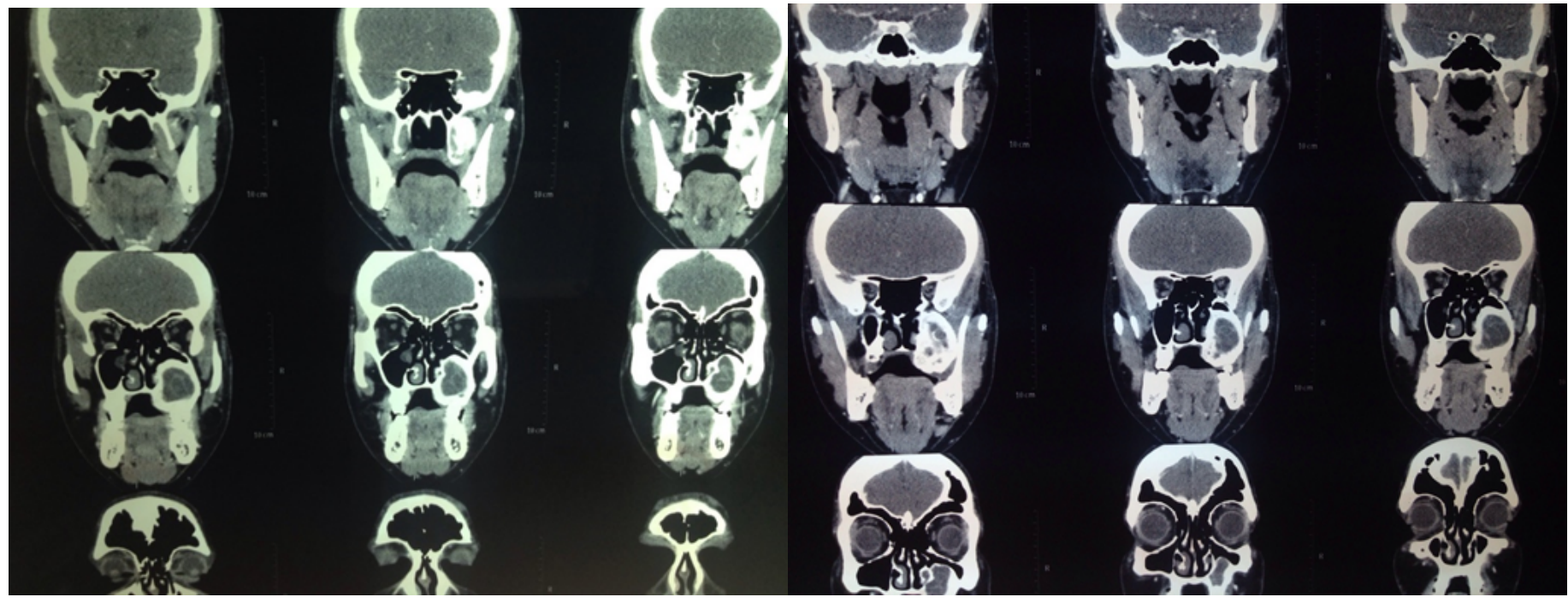

Figure 1. Expansile lesion was originating from the inferior wall of the maxillary sinus. Central soft tissue dansity and peripheral ground glass opacity can be seen.

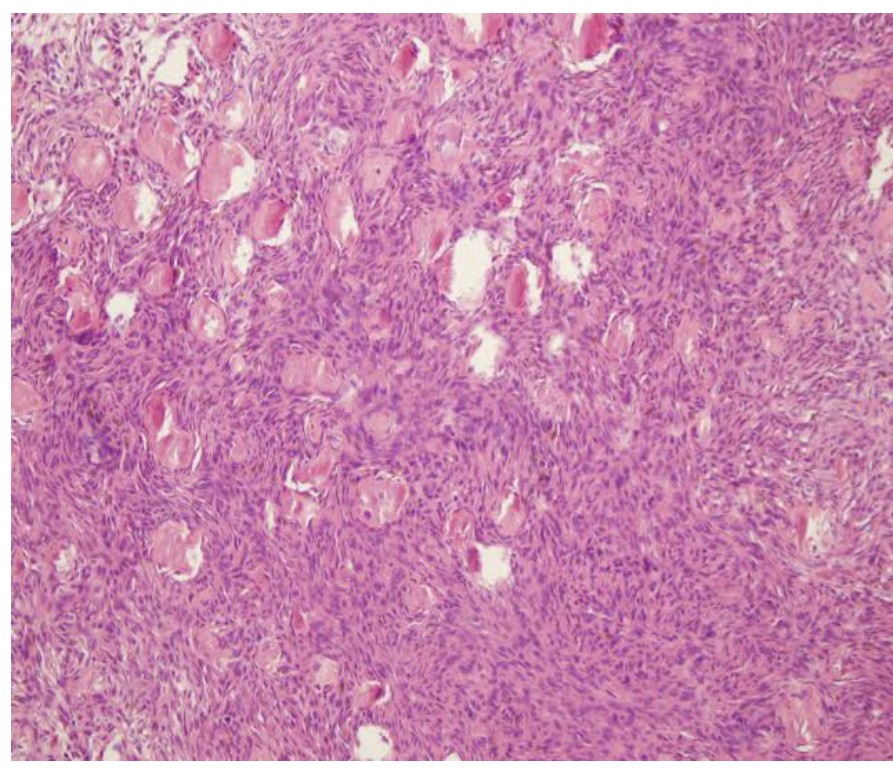

Figure 2. Fibrous dysplasia shows characteristic pattern of woven bone formation and short spindle cells within the stroma (H\&EX200).

from the mass effect of the lesion. The lesions may present with painless mass or may cause symptoms specific to site such as nasal obstruction, headache (Saito et. al.'s patient; 10) and loss of vision (Terkavi et. al.'s patient); 14). Our case presented with mass over the hard palate.

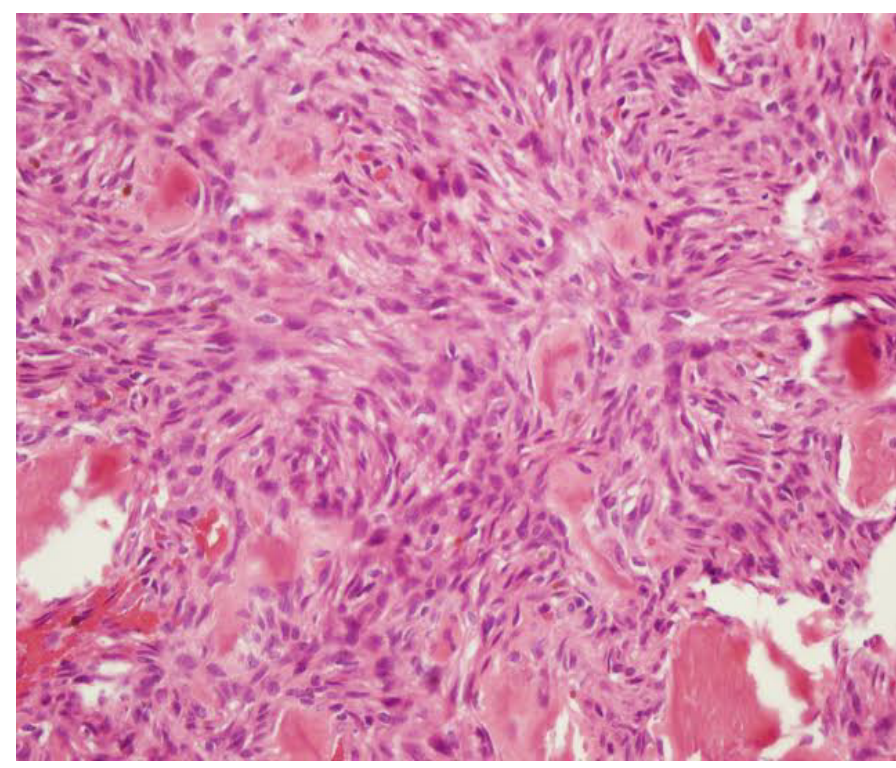

Figure 3. Bland oval to spindle-shaped stromal cells without cytologic atypia surrounds woven bone (H\&EX400).

Consistent with other reports the growth pattern of our case was slow without any compression over vital structures.

Diagnosis of $\mathrm{FD}$ combined with $\mathrm{ABC}$ depends on radiologic and pathologic findings. On radiology the typical appearance of FD 
as ground glass opacity at the periphery of the lesion was detected on CT images combined with cystic soft tissue dansiy in the center. Intraoperative abundant bleeding rouse the suspect of $A B C$ and postoperative definitive pathology confirmed the diagnosis $\mathrm{ABC}$ associated with FD. We believe that typical findings of FD combined with cystic spaces on CT images may be helpful in preoperative differential diagnosis and precautions about bleeding during surgery may be undertaken accordingly.

Optimal treatment of these lesions is total excision. Other treatment modalities are arterial embolization, sclerotherapy, cryotherapy, radiotherapy or combination of these methods but recent studies showed that radiotherapy alone has the risk of post-irradiation sarcoma [15]. In secondary ABC's, such as our case, the treatment plan should be set according to the site of primary lesion. Most of the reported cases (concomitant FD with $\mathrm{ABC}$ ) treated with surgical excision and the results are quite good. We treated our case by total surgical excision. The lesions impingement symptoms and findings or patients with cosmetic problems should be treated by surgery and as fibrous dysplasia has a potential of malignant transformation $(0.5 \%$ of patients with monostotic FD; $4 \%$ of patients with polystotic FD can develop malignant transformation) [16] the patients should be closely monitored. In our case after two years follow-up the patient is well without reccurence.

In conclusion although combination of $\mathrm{FD}$ and $\mathrm{ABC}$ is rare, awareness of such cases may lead preoperative suspect and preoperative and intraoperative precautions on bleeding from $\mathrm{ABC}$.

\section{References}

1. Cholakova R, Kanasirka P, Kanasirka N, Chencev Iv., Dinkova A (2010) Fibrous dysplasia in the maxillo-mandibular region-case report. Journal of IMAB; 16: 10-13.

2. Kransdorf MJ, Sweet DE (1995) Aneurysmal bone cyst: concept, controversy, clinical presentation, and imaging. AJR Am J Roentgenol 164: 573-580. [Crossref]

3. Lichtenstein L (1977) Bone tumors (5th Edn). St Louis: CV Mosby. PP 403-422.
4. Edgerton MT, Persing JA, Jane JA (1985) The surgical treatment of fibrous dysplasia with emphasis on recent contributions from cranio-maxillofacial surgery. Ann Surg 202: 459-479. [Crossref]

5. Albright F, Butler AM, Hampton AO, Smith PH (1937) Syndrome characterized by osteitis fibrosa disseminata, areas of pigmentation and endocrine dysfunction, with precocious puberty in females: report of five cases. NEngl J Med 216: 727-746.

6. Brown EW, Megerian CA, McKenna MJ, Weber A (1995) Fibrous dysplasia of the temporal bone: imaging findings. AJR Am J Roentgenol 164: 679-682. [Crossref]

7. Rapp TB1, Ward JP, Alaia MJ (2012) Aneurysmal bone cyst. J Am Acad Orthop Surg 20: 233-241. [Crossref]

8. Wheeles CR III (2013) Anerysmal bone cyst. In: Wheels CR III (Edr.) Wheels' textbook of orthopedics. Data Trace Internet Publishing, LLC.

9. Kransdorf MJ, Sweet DE (1995) Aneurysmal bone cyst: concept, controversy, clinical presentation, and imaging. AJR Am J Roentgenol 164: 573-580. [Crossref]

10. Saito K, Fukuta K, Takahashi M, Seki Y, Yoshida J (1998) Benign fibroosseous lesions involving the skull base, paranasal sinuses, and nasal cavity. Report of two cases. $J$ Neurosurg 1998, 88: 1116-1119.

11. Skladzierin J, Oles K, Zagolski O, Moskala M, Sztuka M, et al. (2008) A giant cranial aneurysmal bone cyst associated with fibrous dysplasia. B-ENT 4: 29-33. [Crossref]

12. Pasquini Ernesto, Compadretti Ceroni Giacomo, Sciarretta Vittorio, Ippolito Antonio (2002) Transnasal endoscopic surgery for the treatment offibrous dysplasia of maxillary sinus associated to aneurysmal bone cystin a 5-year-old child. Int J Pediatr Otorhinolaryngol 62: 59-62.

13. Lin WC, Wu HT, Wei CJ, Chang CY (2004) Aneurysmal bone cyst arising from fibrous dysplasia of the frontal bone (2004:2b). Eur Radiol 14: 930-932. [Crossref]

14. Terkawi AS, Al-Qahtani KH, Baksh E, Soualmi L, Mohamed Ael-B, et al. (2011) Fibrous dysplasia and aneurysmal bone cyst ofthe skull base presenting with blindness: a report of a rare locally aggressive example. Head Neck Oncol 3: 15. [Crossref]

15. Sanghvi DA, Iyer VR, Chagla AS, Shenoy A (2010) Intradiploic frontal bone aneurysmal bone cyst in a child: a case report. Dentomaxillofac Radiol 39: 252-255. [Crossref]

16. Ruggieri P, Sim FH, Bond JR, Unni KK (1994) Malignancies in fibrous dysplasia Cancer 73: 1411-1424. [Crossref]

Copyright: (C2017 Yollu U. This is an open-access article distributed under the terms of the Creative Commons Attribution License, which permits unrestricted use, distribution, and reproduction in any medium, provided the original author and source are credited. 